\title{
PENERAPAN PRINSIP SUSTAINABLE DEVELOPMENT PADA PERANCANGAN PONDOK PESANTREN ENTERPRENEUR
}

\author{
Achmad Siddiq Annur
}

Andi Baso Mappaturi
Jurusan Teknik Arsitektur, Fakultas Sains dan Teknologi, UIN Maulana Malik Ibrahim Malang e-mail: aansiddiq@gmail.com

Jurusan Teknik Arsitektur, Fakultas Sains dan Teknologi, UIN Maulana Malik Ibrahim Malang

\begin{abstract}
Unhealthy competition among economic actors, and exploitation of natural resources without preservation, caused a complicated problem in the community. Poor-quality education, especially in moral and religious education, to be one of the causes of these problems. Therefore, the existence of boarding school as an educational institution based on Islam is expected to be a solution to decline moral values and religion in this nation. Through a combination of formal and religious education at a boarding school will provide a strong mental training for the formation of individual intelligent and noble. In addition, a boarding school with speech entrepreneurship curriculum in the education system, can provide an added value to the institution. Prospective employers are responsible for each other and the environment, and economic actors are honest and committed. Entrepreneur Boarding can be part of an effort to maintain the sustainability of resources, both natural and human resources. Sustainable development, as the purpose of the object, is a theme that describes every aspect of the design object. Sustainable development has three principles of sustainability; the natural environment sustainability, social sustainability and economic sustainability. Starting from the planning of design, the building process, until the use of the building, always accompanied by the consideration of the three aspects of sustainability. Through the application of sustainable development as the design theme of the boarding school entrepreneurs will produce buildings that are environmentally and socially friendly, in addition to continue to provide investment for owners, users, and the surrounding community.
\end{abstract}

Keywords: Boarding School Entrepreneur, Sustainable Development, Three Dimensions of Sustainable Development

\begin{abstract}
Abstrak
Persaingan tidak sehat antar pelaku ekonomi, serta pemanfaatan sumber daya alam yang berlebihan tanpa diimbangi dengan pelestariannya, kini menjadi permasalahan pelik di tengah masyarakat. Pendidikan yang kurang berkualitas, khususnya pendidikan moral dan agama, menjadi salah satu penyebab atas permasalahan tersebut. Oleh sebab itu, keberadaan Pondok Pesantren sebagai lembaga pendidikan berbasis agama Islam diharapkan dapat menjadi solusi atas menurunnya nilai-nilai moral dan agama pada bangsa ini. Melalui perpaduan antara pendidikan formal dan pendidikan agama pada pondok pesantren akan memberikan pelatihan mental yang kuat untuk terbentuknya individu cerdas dan berakhlak mulia. Di samping itu, pondok pesantren dengan pembekalan kurikulum kewirausahaan pada sistem pendidikannya, dapat memberikan nilai tambah terhadap lembaga pendidikan tersebut. Sehingga dihasilkanlah calon pengusaha yang bertanggungjawab terhadap sesama dan terhadap lingkungan, serta pelaku ekonomi yang jujur dan berkomitmen. Pondok Pesantren Enterpreneur dapat menjadi bagian dari usaha untuk mempertahankan keberlanjutan sumber daya, baik sumber daya alam maupun manusia. Pembangunan yang berkelanjutan atau yang dikenal dengan sustainable development, sebagaimana tujuan dari obyek pondok pesantren enterpreneur itu sendiri menjadi tema yang menjiwai tiap aspek perancangan obyek tersebut. Sustainable development memiliki tiga prinsip keberlanjutan, yakni: keberlanjutan lingkungan alam, keberlanjutan sosial, dan keberlanjutan ekonomi. Mulai dari tahap perencanaan, pembangunan, hingga penggunaannya, selalu diiringi oleh pertimbangan akan keberlanjutan tiga aspek tersebut. Melalui penerapan tema sustainable development pada perancangan pondok pesantren enterpreneur akan dihasilkan bangunan yang ramah lingkungan dan ramah terhadap masyarakat, di samping tetap memberikan investasi bagi pemilik, pengguna, serta masyarakat di sekitarnya.
\end{abstract}

Kata kunci: Pondok Pesantren Enterpreneur, Sustainable Development, Tiga Dimensi Sustainable Development

Pendahuluan
Fenomena sosial yang terjadi saat ini tidak
lepas dari

perekonomian, atau korelasi antara keduanya. Sebagian besar masyarakat memahami tujuan dari pendidikan hanyalah untuk menunjang perekonomian di masa mendatang. Padahal esensi terpenting dari 
eksistensi pendidikan ialah pembentukan karakter serta pengendalian perilaku seseorang. Akibatnya, banyak pelaku ekonomi di negeri ini yang saling bersaing secara tidak sehat, dan saling merugikan satu sama lain. Demi tujuan mendapatkan keuntungan yang sebesar-besarnya, mereka tidak segan untuk melakukan eksploitasi terhadap lingkungan, tanpa ada kesadaran untuk melestarikannya kembali. Melihat fenomena tersebut, perlu adanya pendidikan sikap dan mental yang lebih ketat, agar masyarakat dapat lebih memperhatikan manusia dan lingkungan sekitarnya selain untuk mendapatkan keuntungan semata.

Islam sebagai agama yang dipeluk oleh mayoritas penduduk Indonesia, telah mengajarkan kepada penganutnya untuk selalu menjaga hubungan yang baik dengan Tuhannya, dengan sesama, serta dengan lingkungan alam. Peran manusia sebagai khalifah di bumi, juga termasuk di dalam ajaran Agama Islam. Namun, kurangnya kepedulian terhadap sesama dan terhadap lingkungan alam, banyak terjadi di negeri yang sebagian besar penduduknya beragama Islam ini. Dari sini, terlihat jelas bahwa terdapat hubungan antara kurangnya pemahaman tentang Agama Islam pada masyarakat, dengan rusaknya perekonomian serta eksploitasi alam besar-besaran yang kini terjadi.

Pondok pesantren sebagai lembaga pendidikan berbasis agama Islam memiliki peluang untuk mendidik moral dan perilaku masyarakat Indonesia. Penekanan pada pendidikan anak pesantren atau santri tidak hanya pada ilmu agama dan ilmu umum saja, melainkan juga pada pembentukan pribadi yang beriman, bertaqwa, serta berakhlak mulia. Di sisi lain, sebagai lembaga pendidikan pondok pesantren diminati oleh sebagian besar masyarakat Indonesia yang mayoritas penduduknya muslim. Tercatat ada sekitar 21.521 pondok pesantren di Indonesia dengan jumlah santri yang tidak kurang dari 3 juta orang ${ }^{1}$.Harapannya, melalui pondok pesantren inilah permasalahan ekonomi bangsa dapat terselesaikan.

Perkembangan pesat lembaga pendidikan pondok pesantren di Indonesia mengiringi pula perkembangan keilmuan yang diajarkan di dalamnya. Saat ini klasifikasi pondok pesantren tidak hanya sebatas model yang berbeda antara pondok pesantren salaf dan modern saja. Lebih bervariasi lagi, terdapat beberapa pondok pesantren dengan ciri khas masing-masing sesuai bidang pendidikan yang ditekankan. Contohnya pondok pesantren tahfidz al Quran yang khusus membimbing santri yang ingin menghafal al Quran hingga pondok bahasa asing yang didalamnya menerapkan penggunaan bahasa asing dalam percakapan sehari-hari. Dari fenomena permasalahan ekonomi yang terjadi di Indonesia saat ini, alangkah baiknya jika terdapat pondok pesantren yang menyediakan fasilitas pendidikan perekonomian, yang dalam hal ini adalah wirausaha. Maka perancangan pondok pesantren berbasis wirausaha atau pondok pesantren enterpreneur menjadi menarik untuk dibahas, sebagai solusi atas isu sosial yang terjadi di masyarakat dewasa ini.
Keberadaaan Pondok Pesantren Enterpreneur menjadi sebuah perwujudan integrasi keilmuan, baik integrasi antara ilmu agama dan ilmu pengetahuan umum, integrasi antara ilmu secara teori maupun praktek, integrasi antara ilmu tentang sikap individu terhadap ilmu tentang kemasyarakatan, serta integrasi antara kehidupan dunia dan akhirat. Dalam Islam telah diajarkan tentang pentingnya keseimbangan antara kehidupan dunia dan akhirat, yang dalam firman-Nya berbunyi:

"Dan, carilah pada apa yang telah dianugerahkan

Allah kepadamu (kebahagiaan) negeri akhirat, janganlah kamu melupakan bagianmu dari (kenikmatan) duniawi dan berbuat baiklah (kepada orang lain) sebagaimana Allah telah berbuat baik kepadamu, dan janganlah kamu berbuat kerusakan di (muka) bumi. Sesungguhnya Allah tidak menyukai orang-orang yang berbuat kerusakan." (al Qashash: 77).

Dari ayat tersebut, Allah memerintahkan kepada manusia untuk selalu berusaha mencari kebahagiaan di akhirat dengan selalu beribadah serta menjauhi larangan-Nya. Manusia juga memiliki hak untuk mendapatkan kebahagiaan di kehidupan dunianya dengan belajar dan bekerja keras. Dalam upaya mencari kebahagiaan di dua dunia tersebut Allah memberikan syarat. Syarat yang pertama yaitu manusia harus saling memberikan kebaikan kepada sesama, sehingga dalam beribadah maupun bekerja janganlah sampai merugikan orang lain. Syarat berikutnya, dalam pencarian kebahagiaan di dunia maupun akhirat, Allah melarang manusia untuk merusak alam. Manusia sebagai khalifah di muka bumi harus dapat mengatur keseimbangan alam untuk dapat dimanfaatkan namun dan melestarikannya sekaligus.

Pondok Pesantren Enterpreneur, erat kaitannya dengan prinsip keberlanjutan atau sustainable development. Keberlanjutan dari segi kehidupan sosial masyarakat, keberlanjutan ekonomi masyarakat, serta keberlanjutan lingkungan alam, merupakan tiga aspek yang perlu dipertahankan sebagai prinsip dasar sustainable development atau disebut sebagai tiga dimensi sustainable development. Tujuan utama Pondok Pesantren Enterpreneur pada dasarnya merupakan lembaga pendidikan yang menghasilkan masyarakat berpendidikan dan bermoral, dalam hal ini menunjang keberlanjutan dalam aspek sosial. Di samping itu, kegiatan pendidikan kewirausahaan dalam pondok pesantren ini bertujuan untuk meningkatkan kualitas perekonomian masyarakat, yang dalam hal ini menunjang aspek ekonomi. Sedangkan dari segi lingkungan ditunjang dengan desain perancangan Pondok Pesantren Enterprenenur yang ramah lingkungan dan meminimalisir eksploitasi alam, di samping keberadaannya yang mengharuskan untuk tetap melestarikan lingkungan dalam segala aspek. 


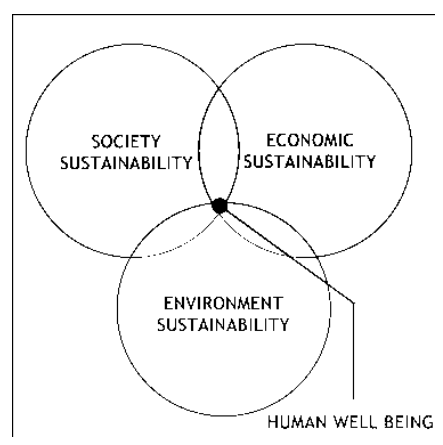

Gambar 1: Tiga Dimensi Sustainable Development ${ }^{2}$

Melalui alasan-alasan itulah, perlu kiranya untuk mengkaji perancangan Pondok Pesantren Enterprenenur dengan menerapkan nilai-nilai keberlanjutan ke setiap aspek rancangannya. Mulai dari penataan massa, bentuk bangunan, hingga material yang digunakan, haruslah menunjang ketiga aspek sustainable. Hingga aktifitas yang dihasilkan melalui perancangan ini juga harus tetap mempertahankan nilai-nilai keberlanjutan.

\section{Hasil dan Diskusi}

Sustainable development, menjadi salah satu strategi pelestarian sumber daya, baik alam maupun manusia. Penerapannya dimulai dari tahap perencanaan, proses pembangunan, hingga proses pengoperasian dan pengembangan. Pemikiran fisik bangunan yang berkelanjutan serta aktifitas didalamnya yang bersifat kontinu harus sudah ada dalam konsep ide perancangan. Pertimbangan prinsip tiga dimensi dalam sustainable development juga harus ada untuk tiap tahapannya. Dengan begitu pelestarian lingkungan, pertimbangan debit dan kredit, serta pengaruh sosial bagi masyarakat menjadi bagian dari tiap proses penyelenggaraan Pondok Pesantren Enterpreneur.

Dalam pembahasan ini akan dijelaskan tentang prinsip tiga dimensi dalam sustainable development, pada pengadaan lembaga pendidikan pondok pesantren enterpreneur. Sustainable development selalu berupaya mempertahankan kelestarian alam, serta menjaga secara moral akan kesadaran mengupayakan efisiensi penggunaan energi dalam aktifitasnya di tiap tahapan penyelenggaraannya, yang dapat dipaparkan sebagai berikut ${ }^{2}$ :

\section{Tahap perencanaan}

Pencarian lokasi yang tepat untuk pembangunan adalah bagian terpenting dalam tahap perencanaan. Ketepatan dalam pencarian lokasi juga dilihat dari aspek tiga dimensi sustainable. Perencanaan dalam desain dan tampilan juga perlu diperhatikan dan dikaitkan dengan prinsip tiga dimensi.

a. Lingkungan
Perencanaan yang baik akan selalu memperhatikan keberlanjutan unsur-unsur alam. Tanah, air, udara, dan api menjadi istilah bagi unsur alam yang perlu untuk dipertahankan.

- Tanah

Dalam pencarian lokasi, perlu untuk memahami kebutuhan obyek terhadap sebuah site yang akan ditempati. Untuk pembangunan Pondok Pesantren Enterpreneur dibutuhkan lahan yang cukup luas. Selain karena kebutuhan akan massa bangunan yang banyak, kurikulum wirausaha yang menjadi nilai tambah dalam pesantren ini membutuhkan lahan tambahan yang cocok sebagai area wirausaha. Untuk mengatasi kondisi ketersediaan lahan yang semakin menyempit di kota besar, dibutuhkan strategi yeng tepat dalam mengolah lahan yang terbatas. Tanah berkontur dapat dijadikan sebagai alternatif, dengan syarat kegunaan lahannya tepat untuk obyek dan sesuai aturan daerah setempat yang diatur dalam Rencana Detail Tata Ruang Kota (RDTRK). Fungsi bangunan yang kompleks menuntut penggunaan lahan untuk area industri, pertanian dan perkebunan, peternakan dan perikanan, serta perdagangan skala desa, selain untuk area pendidikan sebagai fungsi utama.

- Air

Pondok Pesantren pada umumnya memfasilitasi para santri dalam aktifitasnya sehari-hari, terutama kebutuhan air. Kegiatan wirausaha pun diperkirakan membutuhkan konsumsi air yang cukup banyak, sehingga dalam penentuan lokasi, kandungan air tanah pada lahan perlu dipertimbangkan. Adanya sungai yang mengalir dapat menjadi potensi yang sangat menguntungkan selain mengandalkan suplai air bersih dari PDAM.

- Udara

Jauh dari polusi udara menjadi keinginan bagi setiap orang dalam mendirikan tempat tinggalnya. Kendati sulit menghindari polusi udara di area kota, namun strategi dalam peminimalisir masuknya polusi masih dapat dilakukan. Kebutuhan akan penghawaan yang sejuk dan bersih sangat penting diperhatikan dalam tiap ruangan. Intinya adalah membentuk sistem sirkulasi dari penataan massa bangunan yang memungkinkan udara bersih dapat mengalir ke tiap sisi pada site, serta menghindari udara kotor masuk ke dalam site dan ruangan.

- Api

Unsur lain yang penting untuk dipertahankan keberlanjutannya ialah energi, yang dilambangkan oleh api. Kebutuhan akan listrik dalam memenuhi penerangan maupun penunjang aktifitas lainnya tidak kalah dengan kebutuhan terhadap air dan udara. Bahkan untuk menjalankan sebuah kegiatan wirausaha, energi listrik menjadi bagian terpenting yang belum tergantikan. Penataan massa yang memungkinkan dihasilkannya pencahayaan alami 
dibutuhkan dalam perancangan, sehingga mengurangi penggunaan energi. Strategi daylighting pada tiap massa dapat memasukkan cahaya matahari yang optimal. Di samping itu, pengadaan sumber energi alternatif dapat dilakukan untuk menunjang pemenuhan kebutuhan energi yang sangat tinggi pada obyek.

Perlu pertimbangan lebih jauh untuk tetap mempertahankan potensi alami yang ada pada site. Dengan kata lain, desain rancangan haruslah menyesuaikan dengan kondisi asli lahan, bukan mengolah lahan untuk disesuaikan dengan desain bangunan.

b. Sosial

Penentuan lokasi juga tidak lepas dari pertimbangan sosial. Sebagai lembaga pendidikan berbasis agama Islam, pondok pesantren sebisa mungkin berada di wilayah masyarakat bebas konflik antar agama, untuk memperlancar proses pembangunan dan penyelenggaraannya. Keberadaan obyek baik dalam proses pembangunan maupun tahap penyelenggaraan tidak boleh mengganggu masyarakat sekitar. Dalam segi bentuk dan tampilan bangunan, juga diusahakan agar tidak menimbulkan kesan kontras terhadap bangunan di sekitarnya. Lebih baik, keberadaan pondok pesantren enterpreneur dapat menjadi pusat bagi daerah di sekitarnya melalui kegiatan-kegiatan kemasyarakatan.

\section{c. Ekonomi}

Pertimbangan mendasar yang kebanyakan orang anggap sebagai sesuatu yang paling utama yaitu pertimbangan ekonomi. Taksiran terhadap debit dan kredit dalam pembangunan dan penyelenggaraan obyek perlu perhatian khusus. Mulai dari penentuan lokasi, yang berupaya untuk mendapatkan tempat yang memiliki potensi tinggi untuk dimanfaatkan. Pengoptimalan material lokal juga menjadi solusi untuk menekan pengeluaran dalam proses pembangunan. Penentuan lokasi yang strategis dengan pangsa pasar yang tepat juga sangat diperlukan untuk mendapatkan peluang tingginya minat calon santri untuk menuntut ilmu di pesantren enterpreneur sehingga dapat meningkatkan pendapatan ketika proses penyelenggaran pondok pesantren tersebut.

\section{Proses Pembangunan}

Dalam tahap pembangunan, sustainable development memberikan penekanan untuk senantiasa melakukan kebijakan terhadap segala macam sumber daya. Tiga dimensi dalam sustainable development turut menyertai dalam mengambil kebijakan-kebijakan tersebut. Proses pembangunan merupakan pengerjaan atas apa yang telah direncanakan dalam tahap perencanaan.

a. Lingkungan

Sikap bijak dalam mengolah tanah pada site, menjadi keharusan dalam pembangunan dengan tema keberlanjutan. Semaksimal mungkin kondisi asli tanah tetap dipertahankan, untuk meminimalisir kerusakan pada potensi hidup di sekitar site. Potensi alami seperti pohon, sungai, dan kontur tanah tidak dianggap sebagai penghalang dalam proses pembangunan. Potensi alami tersebut justru perlu dipertahankan untuk dapat dimanfaatkan baik dalam proses pembangunan maupun dalam proses penyelenggaraan pondok pesantren nantinya. Cut and fill pada lahan berkontur tetap dilakukan, namun dengan pertimbangan yang seefektif mungkin, untuk menghindari perubahan kondisi lahan yang drastis. Upaya-upaya tersebut juga dapat menunjang aspek keberlanjutan ekonomi, karena biaya pengolahan tanah yang dapat ditekan seminimal mungkin.

b. Sosial

Proses pembangunan yang baik ialah yang tidak menimbulkan keluhan pada masyarakat sekitar atas gangguan yang ditimbulkan. Penggunaan alat berat perlu pertimbangan karena penggunaannya yang menimbulkan polusi baik udara maupun suara atau kegaduhan. Misalnya digunakan hanya jika tenaga manusia tidak sanggup melaksanakannya. Proses pembangunan dengan melibatkan masyarakat setempat akan lebih baik, karena dari situlah akan terwujud rasa kepemilikan dari masyarakat atas obyek. Upaya ini juga dapat menunjang untuk menghasilkan keuntungan dari segi ekonomi.

c. Ekonomi

Seperti yang telah dijelaskan sebelumnya, bahwa dua aspek di atas yaitu aspek lingkungan dan sosial, dalam upaya menjaga keberlanjutannya juga berpengaruh pada aspek ekonomi. Tidak dapat dipungkiri bahwa dalam tahap pembangunan, pertimbangan secara ekonomi menjadi prioritas yang paling diperhatikan. Mulai dari penggunaan material lokal yang relatif rendah biaya, hingga penggunaan sumber daya alam yang dihasilkan oleh potensi lahan itu sendiri, seperti: air, pasir, batu kali, dan lain sebagainya. Dalam usaha meminimalisir biaya, kekuatan struktur juga tetap diperhatikan, karena resikonya akan lebih buruk jika dilihat dari segi ekonomi pada tahap pengembangan nantinya. Penerapan aspek keberlanjutan ekonomi dapat dilakukan dengan menjadikan objek sebagai bangunan yang tumbuh. Dengan kata lain, kebutuhan akan adanya penambahan massa atau penambahan ruang serta renovasi dalam tahap pengembangan nanti, dapat dilakukan tanpa merusak struktur bangunan asli, sehingga mengurangi pengeluaran dari biaya renovasi bangunan tersebut.

\section{Proses Penyelenggaraan dan Pengembangan}

Tahap ini merupakan yang terpenting dalam pengadaan lembaga pendidikan pondok pesantren enterpreneur. Dari sini akan dibuktikan betapa keberadaan Pondok Pesantren Enterpreneur dapat menjadi solusi atas permasalahan moral dan perekonomian pada masyarakat, serta keikutsertaannya dalam mempertahankan keberanjutan sumber daya, baik alam maupun manusia.

Pada tahap ini, pondok pesantren enterpreneur memberikan fasilitas serta membentuk sistem, yang menunjang keberlanjutan dari tiga aspek sustainable development. Beberapa fasilitas yang diberikan Pondok Pesantren Enterpreneur, baik yang berfungsi 
sebagai sarana pendidikan maupun sebagai fasilitas umum, di antaranya:

a. Masjid

Merupakan elemen penting dalam penyelenggaraan pondok pesantren. Kegiatan peribadatan baik yang berupa ibadah mahdoh seperti: solat, dzikir, dan lain sebagainya, serta ibadah yang ghoiru mahdoh seperti: mengaji, diskusi, dan lain sebagainya, dilakukan di tempat tersebut. Masjid di sini berfungsi juga sebagai penunjang aspek sosial, di mana masjid dapat digunakan pula untuk kegiatan kemasyarakatan dengan warga sekitar.

b. Gedung serba guna

Kegiatan santri yang membutuhkan kapasitas ruang yang cukup banyak, seperti seminar, pertunjukan seni religius, atau acara tahunan santri yang bersifat kolektif, dapat dilakukan di bangunan ini. Di samping itu, gedung serba guna juga disewakan untuk umum. Sehingga keberadaan ruang ini menjadi penunjang aspek ekonomi karena menjadi salah satu sumber pendapatan lembaga pondok pesantren.

\section{c. Asrama}

Merupakan salah satu elemen penting pondok pesantren. Asrama untuk santri laki-laki dan perempuan pada umumnya dipisah dengan jarak yang cukup jauh untuk menghindari pergaulan langsung antara santri dan lawan jenis. Asrama menjadi penunjang aspek sosial, di mana seluruh aktifitas santri di dalamnya ditekankan sikap akhlakul karimah, baik dalam aktifitas individu maupun aktifitas bersama. Hal ini akan membentuk moral santri yang baik dan bertanggungjawab, sehingga dapat mengantisipasi kemorosotan moral generasi muda di Indonesia. Pengadaan asrama santri ini juga menunjang aspek keberlanjutan sosial yang baik di tengah masyarakat negeri ini.

\section{d. Sekolah}

Merupakan elemen penting lain dalam pendirian pondok pesantren. Sama seperti sekolah pada umumnya, sekolah atau madrasah di pondok pesantren juga memberikan pendidikan formal berupa kurikulum nasional. Fasilitas ini jelas merupakan penunjang aspek sosial, karena memberikan kemudahan pada santri untuk menuntaskan kewajiban pendidikannya di sekolah.

e. Rumah pengasuh dan guru

Fasilitas ini merupakan perwujudan kepedulian pondok pesantren terhadap para pengajar. Memungkinkan pengasuh atau guru yang bertempat tinggal jauh agar tidak perlu mencari tempat baru di wilayah tersebut. Fasilitas ini juga menunjang aspek sosial dalam upaya memuliakan peran guru yang kini banyak diremehkan.

f. Koperasi pondok pesantren

Fasilitas ini merupakan salah satu penunjang praktek kewirausahaan. Pengelola koperasi merupakan santri pondok pesantren itu sendiri bersama pengasuh sebagai pembimbingnya. Keterlibatan warga sekitar dalam penggunaan fasilitas ini juga diperlukan, sehingga, dapat memberikan penghasilan yang lebih tinggi untuk pemasukan pondok pesantren. Disamping sebagai penunjang aspek ekonomi, koperasi juga menunjang aspek sosial, di mana santri diajarkan untuk berinteraksi dalam kegiatan ekonomi bersama masyarakat.

g. Fasilitas pendidikan kewirausahaan

Merupakan fasilitas penunjang yang menjadi pembeda dengan pondok pesantren lainnya. Pendidikan wirausaha dilakukan dengan memberikan pengalaman langsung untuk merasakan pekerjaan sebagai seorang enterpreneur. Pengalaman tersebut akan menjadikannya ilmu yang sulit untuk dilupakan, sehingga ke depannya dapat dikembangkan ketika berada di lingkungan masyarakat. Selain melatih dalam keahlian berbisnis, fasilitas ini juga memberikan pendidikan moral kepada santri untuk senantiasa bertanggungjawab, baik kepada konsumen, maupun kepada sumber daya alam yang telah dimanfaatkan untuk kegiatan kewirausahaan. Mereka akan berhati-hati dalam mengolah limbah industri agar tidak mencemari lingkungan. Selain itu, tanggung jawab terhadap lingkungan juga dilakukan dengan melestarikan kembali apa yang telah dimanfaatkan untuk kegiatan wirausaha.

Ada berbagai macam bentuk wirausaha. Namun tidak semuanya diajarkan dalam pendidikan wirausaha di pondok pesantren ini. Penekanan kegiatan wirausaha lebih pada pengelolaan alam dan budidaya. Agar pembentukan sikap tanggung jawab terhadap alam lebih dapat tertanam pada jiwa santri. Berikut macam-macam fasilitas wirausaha yang sekiranya dapat diterapkan pada pendidikan wirausaha di Pondok Pesantren Enterpreneur ${ }^{3}$.

Tabel 1: Fasilitas Pendidikan Wirausaha

\begin{tabular}{|c|l|l|}
\hline No & \multicolumn{1}{|c|}{ Fasilitas } & \multicolumn{1}{|c|}{ Kebutuhan ruang } \\
\hline 1 & $\begin{array}{l}\text { Fasilitas } \\
\text { pendidikan } \\
\text { peternakan }\end{array}$ & $\begin{array}{l}\text { Kandang unggas, kandang } \\
\text { kambing dan domba, } \\
\text { kandang kelinci, lahan } \\
\text { rumput gajah }\end{array}$ \\
\hline 2 & $\begin{array}{l}\text { Fasilitas } \\
\text { pendidikan } \\
\text { pertanian dan } \\
\text { perkebunan }\end{array}$ & $\begin{array}{l}\text { Lahan untuk sawah, lahan } \\
\text { untuk perkebunan, ruang } \\
\text { persemaian (germinator } \\
\text { room), ruang pengomposan } \\
\text { (composting), lumbung } \\
\text { padi adi tawar, }\end{array}$ \\
\hline 3 & $\begin{array}{l}\text { Fasilitas } \\
\text { pendidikan } \\
\text { perikanan }\end{array}$ & $\begin{array}{l}\text { Kolam ikan air tan pembibitan dan } \\
\text { kolam } \\
\text { pengembangan lele, kolam } \\
\text { pembibitan dan } \\
\text { pengembangan mujair }\end{array}$ \\
\hline 4 & $\begin{array}{l}\text { Fasilitas } \\
\text { pendidikan } \\
\text { keahlian }\end{array}$ & $\begin{array}{l}\text { Lab computer, ruang } \\
\text { praktek memasak, ruang } \\
\text { praktek menjahit, ruang } \\
\text { praktek kecantikan }\end{array}$ \\
\hline
\end{tabular}


Di samping fasilitas, aktifitas pun perlu diperhatikan dalam penyelenggaraan kegiatan pendidikan di pondok pesantren. Melalui fasilitas-fasilitas yang telah disebutkan di atas, diharapkan dapat menghasilkan aktifitas-aktifitas yang juga menunjang keberlanjutan dari tiga dimensi sustainable development. Sehingga, keberadaan pondok pesantren enterpreneur benar-benar dapat mendukung upaya keberlanjutan baik pada lingkungan, sosial, maupun ekonomi.

\section{Kesimpulan}

Penerapan prinsip tiga dimensi sustainable development, memperkuat keberadaan Pondok Pesantren Enterpreneur sebagai lembaga pendidikan yang mencetak wirausahawan yang bertanggungjawab. Tidak hanya dari desain bangunannya saja, penerapan prinsip sustainable development menjiwai seluruh tahap pengadaan Pondok Pesantren Enterpreneur, antara lain:

- penentuan lokasi yang tepat dan berpotensi dari segi ketersediaan sumber daya alam, kondisi mayarakat, serta peluang penyelenggaraan kegiatan wirausaha.

- $\quad$ proses pembangunan yang bijak terhadap alam dan masyarakat, dengan meminimalisir penggunaan alat berat, dan mengoptimalkan penggunaan material alami.

- $\quad$ penyelenggaraan pendidikan pondok pesantren enterpreneur dengan fasilitas dan aktifitas yang tepat dan menjunjung tinggi prinsip keberlanjutan tiga dimensi sustainable.

Dari pemaparan secara umum tersebut, dapat dikembangkan lagi untuk lebih detailnya tentang penerapan prisip sustainable development pada tiap aspek perancangan secara lebih detail.

\section{Referensi}

1 http://www.scribd.com/astaga/d/ 24613026 Depag -LaporanKhusus-Prestasi-Santri-danMurid-Madrasah-Meningkat-Signifikan

2 Ian L McHarg, penerjemah Sugeng Gunadi. 2005. Merancang Bersama Alam. Airlangga: Surabaya

3 Guzairi, Ahmad Faiz. 2010. Desain Tata Ruang Kamar di Pesantren. UIN-Maliki Press: Malang 